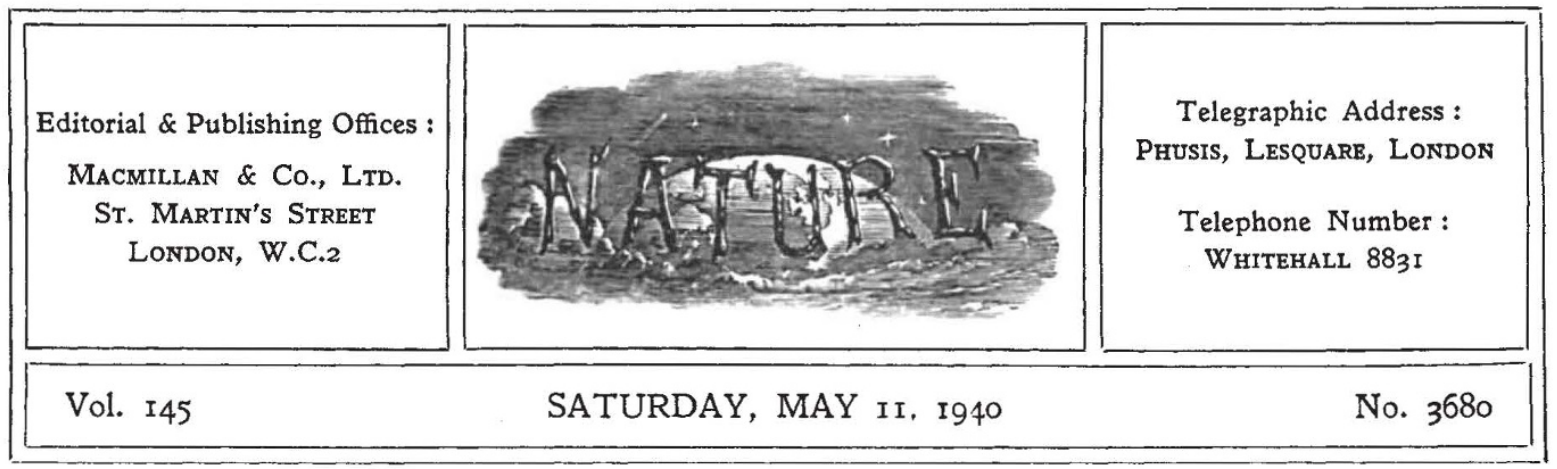

\title{
BOOKS IN WAR-TIME
}

W ILL books be made subject to the Sales Tax proposed by the Chancellor of the Exchequer, and if so what may be the results? So far as can be ascertained up to the present it is not proposed to allow any exceptions in the home market, outside the domain of food and drink, and the resultant anxiety of all who are familiar with book-trade economics would undoubtedly be shared by every thinking man if the very special facts of the case were generally under- stood. In the following very brief survey of a very complex problem, it has been impossible to attempt more than the sketchiest of outlines, but it may be hoped that it will do something to correct some common misapprehensions and perhaps enlist some sympathy for the claim of books to special consideration. This claim has been emphatically put forward by the National Book Council, in an urgent call for action recently circulated to every society and association of a cultural nature.

To the printed book we owe the preservation of the philosophy, the scientific knowledge, the religion and the poetry of the past. Upon the book depends the comparative examination of rival theories, the precise record of all experimental work. In short, civilization as we know it to-day is the child of the printed word, and upon the printed word, written under the twin inspirations of intellectual freedom and love of truth, depends all hope of further progress.

Out of the almost universal recognition of these truisms there has arisen a tradition, never yet over-ridden in Great Britain, that a tax upon books would constitute an unfortunate impediment to free speech and a tax upon literature and learning. It is therefore not surprising to find that the National Book Council is exerting itself actively to organize, before it is too late, effective opposition to the proposition now under review. The National Book Council was founded in 1927 to promote the use and appreciation of books of all kinds, from the novel to the technical treatise, and the membership is open to all who care for books.

The letter to which reference has already been made was sent at the instance of this body's Consultative Committee, through which is maintained liaison with many of the most important educational bodies, learned societies and social organizations in the country.

In this Committee's manifesto, it is claimed that the application of a sales tax to books would be "inimical to the best interests of research, study and recreation", and that "in addition it would tend to disrupt still further the whole educational programme of the nation-a programme already suffering from disorders caused by the war". Let us examine this claim.

The Chancellor of the Exchequer, in introducing the principle of the sales tax, made it clear that its purpose is at least as much to discourage internal expenditure as to raise funds towards the successful prosecution of the War, and from this it is fair to assume that in the eyes of the Government books are to be regarded simply as a commodity, just like any other, the consumption of which must be discouraged as cheerfully as, perhaps, the luxury cosmetic or the unnecessary spare suit. This attitude, which is discouraging to all who deplore the widespread tendency to regard books as luxuries, cannot be allowed to pass unchallenged, if the nation is not to find itself without books, publishers to produce them or 
booksellers to sell them. Fortunately there is hope of persuading the Government that books have, quite apart from their cultural influence, a very considerable economic value to the nation at war, besides being absolutely essential to the presentation of the British case to the eye of ally and neutral.

In this connexion we cannot do better than quote the following paragraph from a "Memorandum on the Export of Books" submitted to the Export Council by the Publishers' Association: "The 'cultural' value of books is unique. The word 'cultural' does not at all adequately express what we have in mind and has narrow academic associations which we would gladly avoid. Nor is 'propagandist' a better word. What the book trade does, in general and apart from the particular purposes of particular books, is to publicize British habits, ideas and ideals over the entire world. It is consequently a continuing proof of the reality of the Allied Cause. The variety, vigour and freedom of British civilization are demonstrated through the whole range of its literary output, from the ordinary novel to the most serious critical and scientific works : and this continuous process cannot be allowed to flag without endangering British influence and prestige everywhere."

It has been repeatedly stressed that, for economic reasons, whatever happens to our internal trade, neither the proposed sales tax nor any other wartime legislation should interfere with British export trade. But apparently it is not realized that books, unlike most commodities or manufactured products, cannot be divided up into two water-tight compartments-home and export. The largest part of a book's production cost is the cost of setting up the type, and as this remains the same whether it is to be printed by the hundred or the thousand, it is clear that the largest possible circulation must be aimed at if the price is to be kept at an economic level. Another large fixed expense is the cost of placing the type on the printing machine and of 'making ready' for printing, a skilled and laborious job which is carried out by highly paid craftsmen. By the influence of these two factors is to be explained a large part of the price differences between newly printed books at $7 s .6 d$. and more, cheap editions and reprints from standing type at $3 s$. $6 d$. to $1 s$. $6 d$., and "Penguins" at $6 d$. each which, though completely reset, spread the cost over editions of thirty to fifty thousand.
This being so, it is clear that if attractive pricelevels are to be maintained in the export markets, the maximum home demand must be encouraged. If the home demand is artificially cut down editions will shrink, and prices will rise so sharply as to destroy the potential demand abroad and make impossible the publication of many books of the first importance. There are unfortunately no reliable statistics in the book trade, but a recently circulated questionnaire has shown not only that at least one third of the total book production of Great Britain is sold abroad, but that, in addition, valuable invisible exports are created by the sale of American film rights. If we add to this consideration the claim that the export of British books does much to unite the Empire, to demonstrate the British outlook and ideals all over the world and, incidentally, to prepare the way for the exporters of other British goods, we may reasonably conclude that its importance to the nation is out of all proportion to its monetary value.

It will be generally agreed that on cultural grounds alone, book prices should be maintained within a reasonable distance of preWar levels. Unfortunately this aim becomes increasingly difficult of achievement, and it seems likely that the strenuous efforts to stabilize prices, which maintained them at pre-War level for the first three months of the War, will be utterly defeated by the situation in Scandinavia. An important factor in price fixing is the cost of paper, and the cheaper the book the more relatively important does this factor become. At the onset of the War, the Government took over the control of all paper supplies. A controller was appointed and a schedule of maximum prices was worked out, promptly imposed, and linked to a drastic rationing scheme which reduced the nation's consumption to 60 per cent of pre-War requirements. This restriction, combined with a heavy percentage increase in the price of paper, had already forced up the price of the standard cheap editions and of many, but not all, of the new spring books, when the Germans invaded Norway and attained the control of the Skagerrak by the occupation of Denmark.

The larger part of the wood pulp supplies which form the basis for most of our paper was cut off at a stroke and no one knows when, or if, it will be available again. The ressult was immediate and startling. A further increase in prices coincided with a 50 per cent cut in permitted consumption, and this was followed by an 
announcement that after the current licensing period a further severe cut in consumption, possibly up to another 50 per cent, will be necessary. At the time of writing, therefore, the book trade is wondering what it can usefully do with 15 per cent of its pre-War paper consumption, at prices more than 60 per cent above pre-War levels.

With wages, rates and fuel costs rising in competition, with compulsory war risks insurance to pay, and with the problems of evacuation to contend with, the situation was already critical for bookseller and publisher alike. Increased production costs call for 'Ionger runs', but such a scarcity of material will not only make this impossible but also will necessitate, on the contrary, much smaller editions than usual. It is difficult therefore to see how publishers will be able to avoid for much longer a dangerous increase in price-levels at a time when Government policy is to prevent general inflation and, by taxation, both direct and indirect, to limit internal expenditure. Already, we believe, the sale of new fiction and general literature has dwindled to a fraction of its pre-War volume, but the demand for books on the War and international politics, official Blue Books, memoranda and handbooks, together with standard cheap editions of the classics, old favourites and popular reference books, has gone far to cancel out the drastic effect of the evacuation in London and other evacuation areas, while elsewhere business has been quite brisk. But the War has scarcely begun, paper shortage has only just begun to take effect, and the real price increases are not yet upon us, though close at hand. The outlook of the immediate future, so far as book production is concerned, is gloomy in the extreme.

To this situation is now added the threat of a sales tax which may be anything from 5 to 25 per cent on to prices which by then will already have risen. Such an impost would be a veritable tax on literature and culture. Books are often the first objects of personal economy, and this can unfortunately also be said with equal truth of the councils and committees of local government and public education. Even in peace-time conditions expenditure per head on books in Great Britain is very much below that which is accepted as normal to the Finns, the Germans the Scandinavians or the French. As has been said, no statistics exist, but it has been possible to make approximate estimates within a generous margin of error, and as a typical illustration it may be of interest to recall that according to the estimate of the Consultative Committee on Books in Public and Elementary Schools which reported to the Board of Education in 1928, the average annual expenditure on books, per head, was certainly not in excess of $1 s .8 d$, and it has not shown much sign of improvement since that date.

Were there greater mental alertness and intellectual curiosity, books would be able to perform adequately the service which they now offer too often in vain, and their producers would be able to supply, at prices within the range of every pocket, new works of literature, of learning and of reference which at present are confined to the shelves of the libraries and the dwindling regiment of the bibliophiles. It is to extend and develop this wider interest in, and appreciation of, books that the National Book Council was formed.

The production of books is authoritatively stated to consume only 2 per cent of the nation's normal paper supplies, and a reversion to the earlier allowance of 60 per cent of normal, which would enable the publishers to carry on with reasonable efficiency, would therefore call for the re-allocation of about 1 per cent of the nation's pre-War supplies. In practice, by careful selection and economy in production, it would probably be possible for the book trade to carry out its important functions on an even lower allowance; but precisely how much this would be is probably best left to the Publishers' Association.

The present international crisis threatens to bear with undue weight on book production. Learned and educational organizations may be expected to give active support to the appeal for special consideration for books. If disaster to the intellectual life and the intelligent recreation of the nation is to be avoided, books should be exempted from the sales tax and accorded a wholly disproportionate share of the available supplies of their raw material-paper.

Long-range planning is a necessity in bookproduction as in many other fields, and without an early pronouncement on the position, an important part of the nation's effort is being held up. The case appears to be so strong that the urgent representations now being made can, one may hope, scarcely fail to have their effect. But the desired result will be more quickly and more completely attained if all those who realize the place of books in the social, intellectual and economic fabric of the nation use their influence wherever it may be most effectively applied. 